\title{
A TECHNOLOGY FOR DEVELOPING PROFESSIONAL COMPETENCÅ OF VOCATIONAL TRAINING TEACHERS
}

\author{
Svitlana Kravets, \\ Candidate of Pedagogic Sciences (PhD), Senior Researcher Officer at the Laboratory of Distant Professional Training at the Insti- \\ tute of Vocational Education and Training of NAES of Ukraine \\ http://orcid.org/0000-0002-8878-6241, e-mail: sveta.kindz@ukr.net
}

\begin{abstract}
.
The relevance of constant professional development for teaching staff in professional (vocational) education schools $(\mathrm{P}(\mathrm{V}) \mathrm{E}$ schools $)$ is conditional upon the innovative changes in education, the modernization of educational and industrial technologies and the elaboration of effective models and mechanisms of training highly qualified personnel. The professional development of masters of vocational training is correlated with the development of their professional competency, integrating the so-called systematic build-up of new knowledge and experience.

The article aims to justify a particular technology for developing professional competency in masters of vocational training from $\mathrm{P}(\mathrm{V}) \mathrm{E}$ schools.

Methods include a theoretical analysis of scientific works, a study of practical experience, systematization, generalization and a pedagogical experiment.

Results. The results of the survey of teaching staff (including masters of vocational training) regarding the final level of professional motives confirm the following: a high level-29\%, a sufficient level- $56 \%$, an average level $-15 \%$. The results of these specialists' self-assessment of their readiness for professional development are as follows: a high level $-48 \%$, a sufficient level $-47 \%$, an average level $-5 \%$. The paper proves that there appears to be a need to discover some optimal technologies for developing professional competency in masters of vocational training, given the conditions for elaborating modern models of teacher education. An algorithm for designing the technology for developing professional competency in masters of vocational training from $\mathrm{P}(\mathrm{V}) \mathrm{E}$ schools includes a scientific aspect (defining and adhering to targets, objectives, methodological and other principles of professional education), a procedural aspect (modelling the content, forms and methods for developing professional competency) and a result-oriented aspect (identifying the level of professional competency in masters of vocational training based on appropriate methods and self-analysis).

Conclusions. The paper presents the technology for developing professional competency in masters of vocational training from $\mathrm{P}(\mathrm{V}) \mathrm{E}$ schools as a psycho-pedagogical process organized according to an appropriate algorithm, whose implementation should result in the professional development of masters of vocational training.

Keywords: professional development, professional competency, master of vocational training, technology for developing professional competency in masters of vocational training.
\end{abstract}

Introduction. Modern reforms in the national education, including professional (vocational) education $(\mathrm{P}(\mathrm{V}) \mathrm{E})$, are accompanied by innovative changes aimed at the modernization, a systematic introduction of modern educational and industrial technologies into the educational process and the creation of effective models and mechanisms for training highly qualified personnel. Given this, it becomes essential to develop professional competency in modern teachers and masters of vocational training, who should able to solve significant educational problems. The Law of Ukraine "On Education" (Art. 54, Clause 2, 2017) 
states that teaching staff must continuously improve their professional and general cultural level and pedagogical skills. The National Strategy for the Development of Education in Ukraine until 2021 (2013) refers to training a new generation of teaching staff, raising the level of education, pedagogical skills, the professional culture of teaching staff (Legislation of Ukraine, 2013). The Concept of Teacher Education Development (2018) envisages an improvement in the system of teacher education to establish a training base for teaching staff of a new generation, create conditions for involving the best practitioners of other professions in educational activities and ensure the establishment and development of modern alternative models on constant professional and personal development, which will become a critical condition for implementing the state policy into reforms in all divisions of education (Legislation of Ukraine, 2019). The analysis of legislative acts proves the relevance of professional growth for masters of vocational training. After all, it involves the development of their professional competency for solving not only educational tasks. It is also essential for the development of the country's economy and the personal growth of various specialists.

Materials. Such scholars as A. Hurzhii, V. Kremen, L. Lukianova, N. Nychkalo, V. Radkevych and $\mathrm{O}$. Shcherbak theorize about the conceptual views on the development of the personality of teachers or masters of vocational training in the system of continuing professional education. They think that "continuing education is a process of personal, social and professional development of the individual throughout his or her life, which aims to improve the quality of life of both the individual and society" (Lukianova, 2017, pp. 4). There has been much speculation about the issues of training masters of vocational training and developing their professional competency (Yu. Belikova, T. Gerliand; L. Komisarova, H. Omelchenko, Z. Turianytsia, O. Yurtaieva et al.). They believe that there are different ways to solve the issue of adjusting the professional competency of masters of vocational training to modern needs of the national professional education. In this context, one should pay specific attention to developing cultural attitudes in masters of vocational training especially regarding professional and pedagogical culture, as well as the culture of personal and professional development, shaped while studying in $\mathrm{P}(\mathrm{V}) \mathrm{E}$ schools and under the influence of external factors, including the trends in the labour market. Such researchers as M. Artiushyna, S. Kravets, P. Luzan and H. Romanov study theoretical principles for building the content of education and introducing innovative educational technologies The concept of educational technology is understood as a system of the educational process and specially organized educational activities aimed at the development, education, learning and character building of the individual.

Thus, current conditions for reforms in the $\mathrm{P}(\mathrm{V}) \mathrm{E}$ system substantiate the importance of constant professional development of teaching staff. It causes the search for some optimal ways to develop professional competency in masters of vocational training in the context of using and improving the existing effective educational technologies and justifying new and multifunctional methods corresponding to the content of modern models of teacher education.

The article aims to justify an algorithm for designing the technology for developing professional competency in masters of vocational training from $\mathrm{P}(\mathrm{V})$ E schools.

Methods include the following: a theoretical analysis of psycho-pedagogical literature, scientific works, dissertations in the field of pedagogy, a study of practical experience - to describe the characteristics of professional development of masters of vocational training; a pedagogical experiment (the ascertaining stage) - to identify the existing level of professional competency in masters of vocational training; analysis, synthesis, generalization - to specify the technology for developing professional competency in masters of vocational training.

Results and discussion. In the context of economics and sociology, professional development correlates with the development of performance potential or staff development through searching for the ways to improve the activities of educational institutions and increase the value of teaching staff. From the standpoint of psychology, professional development involves psychological changes related to changes in the mind and behaviour of the individual, the emergence of new motives and interests, the acquisition of new mental capacities. In pedagogy, professional development of the individual occurs when solving professionally important tasks (cognitive, communicative and moral). At this particular time, teachers acquire a basic set of necessary business skills and moral qualities related to their profession. The analysis of professional self-development of masters of vocational training involves comparing the results of educational activities with those criteria, envisaged by the requirements of education policy, economic development and personal aspirations for self-realization. The Concept of Implementation of the State Policy in the Field of Professional (Vocational) Education "Modern Professional (Vocational) Education" until 2027 highlights the importance of motivation towards cultivating professional development of teaching staff by involving highly qualified experts in production 
and the service sector in the educational process (Legislation of Ukraine, 2019). Indeed, the active professional development of masters of vocational training encompasses conscious personal needs and their professional motives in professional growth and lifelong learning. The results of the survey of employees from $\mathrm{P}(\mathrm{V}) \mathrm{E}$ schools prove the sufficient level of their motivation towards professional development. Fifty-six per cent out of 36 respondents feel sufficiently motivated towards professional development. The remaining $29 \%$ and $15 \%$, respectively, are at high and average levels of motivation towards professional development.

A self-analysis of the professional development of masters of vocational training needs to answer the following questions: "Can I develop the personality of the pupils, make them more responsible for their professional future and development?"; "Can I engage in creative activities in $\mathrm{P}(\mathrm{V}) \mathrm{E}$ schools of different types?"; "Can I work in a new environment, adapt to changes and respond to modern and promising processes of social and economic development of society promptly?". Answering these and other questions, every master of vocational training is reconsidering his or her role in professional activities and is searching some ways to improve his or her professional skills, professional competency and enrich his or her culture (Kravets, 2019, pp. 317). In 2019, the employees of the Laboratory of Distant Professional Training at the Institute of VET of the NAES of Ukraine, within the framework of working on the professional standard for the profession "Master of Vocational Training", surveyed the masters of vocational training from Ukrainian $\mathrm{P}(\mathrm{V}) \mathrm{E}$ schools about the importance of employment functions and their readiness for their performance. Consequently, the masters of vocational training from 18 Ukranian Oblasts completed e-questionnaires on self-assessment of their readiness for professional development, which correlates with the development of professional competency. The analysis of these e-questionnaires shows the following results: $48 \%$ out of 1056 respondents think they are at a high level of readiness for professional development. The remaining 47\% and $5 \%$ are at sufficient and average levels. It must be acknowledged that nobody indicated a low level of such readiness.

In the context of designing a new model of professional education, teaching staff are the primary agents of change, as well as active participants in its development and approval. Given this, educational activities of masters of vocational training in $\mathrm{P}(\mathrm{V}) \mathrm{E}$ schools exceed the implementation of syllabi for relevant subjects and become multifunctional. It refers to an active participation of masters of vocational training in the implementation of strategic objectives of the educational sector; the ability to design the content of training for future skilled workers; the provision of inter-branch communication; the management of educational projects; the elaboration of integrated models for professional training which combine traditional methods and modern educational technologies (Radkevych, Luzan and Kravets, 2017, pp. 265). Therefore, the development levels of professional competency reflect the professional-pedagogical development of masters of vocational training. However, professional competency is not a permanent category. It implies the so-called systematic build-up of new knowledge and experience through self-study, formal and non-formal education, internships, lifelong learning through higher education (master's and doctoral degrees), certification within the framework of participation in Ukrainian and international projects; cooperation and interaction between pupils, parents, teaching staff, school leaders, management structures in education, employers, higher education institutions, academic institutions and other public organizations. Given this, every master of vocational training should be aware of his or her mission in these constructive changes. Besides, a systematic boost of his or her readiness to implement educational and industrial innovations will transform the demands of the labour market during vocational training of future skilled workers through expanding professional skills and abilities of masters of vocational training. It necessitates an active search for different forms, methods and technologies to develop professional competency following the needs of masters of vocational training, pupils, educational institutions, cultural characteristics and economic problems.

The analysis of scientific works and encyclopedias shows that it is necessary to follow a specific algorithm for achieving expected results to solve relevant tasks in the field and increase the productivity of workers. The concept of technology integrates the set of goals, content and information about the sequence of individual operations in the production process, methods and means of achieving expected results. In the education system, this concept is implemented at the level of solving strategic tasks for the education system (educational technology). It also reflects the tactics of implementing educational technologies in the educational process under certain conditions (pedagogical technology) and models the way of developing specific educational material (concept) within the relevant academic subject, topic, issue (teaching technology) (Sorokvashyn, 2018, pp. 99). In the context of the educational process, the mission of masters of vocational training implies implementing technologies at all levels. However, it is vital to justify the appropriate technology, whose essence, purpose and content correlate with the innovative trends in professional education, to improve their educational activities and enhance their professional competency. 
The technology for developing professional competency in masters of vocational training is inextricably linked with educational activities. Also, it incorporates the principles of systematic, cultural, humanistic, competency-based, subject-oriented, personality-oriented, developmental and prognostic approaches, continuation principles and combines theory, productive activity and lifelong learning. It refers to the scientific aspect of the technology, with defining its purpose and objectives.

Therefore, this technology aims to develop professional competency in masters of vocational training through using a personal potential, resources of the educational environment and opportunities for social partnership for constant professional development, self-improvement and productivity in the field of professional education. The objectives of this technology are as follows: to boost motivation of masters of vocational training towards self-development; to create relevant conditions for developing professional competency in masters of vocational training; to discover the practical ways, forms, methods and tools for it; to ensure constant professional development of masters of vocational training so that they can engage in educational (intellectual, creative) activities, "aimed at education and development of the individual, his or her cultural, civic and / or professional competencies" (Legislation of Ukraine, 2017).

The procedural aspect of this technology implies a specific algorithm for its implementation in the educational environment, production and the service sector. This stage involves the mobilization of all personal, instrumental and methodological tools for developing professional competency in masters of vocational training. Given the innovative progress of production, technological changes and growing demands of the labour market, the technology for developing professional competency in masters of vocational training should integrate the psycho-pedagogical aspect of interaction between teaching staff and pupils while implementing a standardized content of professional training, exceed the educational environment, employ resources of a public-private partnership and capacities of dual education to study the current trends in production and the service sector. Besides, this technology should be advanced, open to rethinking and adjust to the new requirements and priority areas in the country's development (Kravets et al., pp. 11).

The results of the survey of employers regarding the possibilities and frequency of using specific forms for enhancing professional skills of employees indicate that the most common ones are advanced training (in-service training (87\%), internships in production (57\%); retraining (in educational institutions (79\%), in production $(65 \%)$ (The Institute of Professional Qualifications, 2019).
The development of professional competency in masters of vocational training cannot be limited by advanced training scheduled in advance. In the context of the introverted (closed) pedagogical system, it should be an active process and involve studying some positive practices of teaching staff (mentors); participating in the work of methodological commissions, mentoring schools, novice masters of vocational training; exchanging experience, mutual visits and assistance; holding methodological seminars, workshops, scientific and practical events. The potential of the extroverted (open) pedagogical system focuses on the complex integration of the educational process with organizational and technological processes in production under the established social partnership between educational institutions and enterprises. Besides, it serves as an essential resource for developing professional competency in masters of vocational training. It refers to "removing" the technology for developing professional competency in masters of vocational training from the introverted (closed) pedagogical system and expanding forms of professional development by using resources of the extroverted (open) pedagogical system. The technology for developing professional competency in masters of vocational training combines optimal resources of introverted and extraverted pedagogical systems for gaining formal and non-formal experience and constant professional development of both teaching staff and pupils.

The result-oriented aspect of this technology involves identifying the final level of professional competency in masters of vocational training and conducting self-analysis on a reflexive basis. Reflective processes regarding well-developed or underdeveloped professional competency rely on the ability of masters of vocational training to regulate professional activities and realize the goals, objectives and functions of the educational process. At the same time, one rethinks his or her experience, professional successes or failures and manages individual psychological processes to continue professional development.

Conclusions. Therefore, the technology for developing professional competency in masters of vocational training from $\mathrm{P}(\mathrm{V}) \mathrm{E}$ schools is an organized psycho-pedagogical process incorporating scientific approaches and principles. One can implement it based on innovative forms, methods, means of training and self-study. This technology guarantees the professional development of masters of vocational training. The algorithm for designing this technology includes scientific, procedural and result-oriented stages. They involve defining and adhering to the targets, objectives, methodological and other principles of professional education; modelling the content, forms and methods for developing profes- 
sional competency in masters of vocational training; identifying the level of professional competency in masters of vocational training based on self-analysis and methods adapted in pedagogy and psychology. The content of this technology should be advanced, open to rethinking and adjust to the new requirements and priority areas in the country's development, including the integration of the national education into European educational space.

\section{List of referenses}

Герлянд, Т. 2011. Структурно-змістові аспекти професійної компетентності майбутніх кваліфікованих робітників. Науковий вісник Інституту професійно-технічної освіти НАПН Украӥни. Професійна педагогіка, 2, с. 30 -34.

Законодавство України (Верховна Рада України), 2013. Про Національну стратегію розвитку освіти в Україні на період до 2021 року: Указ Президента України від 25.06.2013 № 344/2013. [online] (Останнє оновлення 04 Липень 2013) Доступно: <https://zakon3.rada.gov.ua/laws/show/344/2013> [Дата звернення 10 Вересень 2019].

Законодавство України (Верховна Рада України), 2017. Про освіту: Закон України від 05.09.2017 № 2145-VIII. [online] (Останнє оновлення 09 Серпень 2019) Доступно: $<$ http://zakon2.rada.gov.ua/laws/show/2145-19/page/> [Дата звернення 10 Вересень 2019].

Законодавство України (Верховна Рада України), 2019. Про схвалення Концепції реалізації державної політики у сфері професійної (професійно-технічної) освіти «Сучасна професійна (професійно-технічна) освіта» на період до 2027 року: Розпорядження Кабінету Міністрів України від 12.06.2019 № 419-р. [online] (Останнє оновлення 12 Червень 2019) Доступно: <https://zakon.rada.gov.ua/laws/show/419-2019-\%D1\%80> [Дата звернення 10 Вересень 2019].

Інститут професійних кваліфікацій, 2019. Аналіз потреб ринку праиі, викликів та можливостей на території Східної України: Попередній звіт. [online] Доступно : <http://ipq.org.ua/upload/files/files/03_Novyny/2019.05.15_Zvit/ IPQ_Report_09.05.19.pdf> [Дата звернення 10 Вересень 2019].

Кравець, С. Г., 2019. Професійний розвиток сучасного педагога в контексті реформування професійної освіти. В: Розвиток професійної майстерності педагога в умовах нової соціокультурної реальності: II Міжнародна наук.-практ. конф., Ч. 1. Тернопіль, Україна, 11-12 Квітень. 2019. Тернопіль: Тайп.

Кравець, С. Г., Кравець, Ю. І., Дерев'янко, Н. П. та Оліферчук, О. Г., 2014. Педагогічні основи формування змісту підготовки кваліфікованих робітників за інтегрованими професіями: посібник. Київ: Поліграфсервіс.

Лук'янова, Л., 2017. Законодавче забезпечення освіти дорослих: зарубіжний досвід. Київ: ДКС-Центр.

Міністерство освіти України, 2018. Про затвердження Концепиії розвитку педагогічної освіти: Наказ МОН Украӥни від 16.07.2018 №776. [online] (Останнє оновлення 16 Липень 2018) Доступно: <https://mon.gov.ua/ua/npa/ pro-zatverdzhennya-koncepciyi-rozvitku-pedagogichnoyi-osviti> [Дата звернення 10 Вересень 2019].

Радкевич, В. О., Лузан, П. Г. та Кравець, С. Г., 2017. Стандартизація професійної освіти в контексті євроінтеграційних процесів. В: Наукове забезпечення розвитку освіти в Украйні: актуальні проблеми теорії $і$ практики (до 25-річчя НАПН України). Київ: Видавничий дім «Сам», с. 259-267.

Сороквашин, С. В., 2018. Формування інформаційно-комунікаиійної компетентності майбутніх кваліфрікованих робітників будівельної галузі у прочесі професійної підготовки. Кандидат наук. ВНЗ «Університет імені Альфреда Нобеля».

Bazyl, L. O., Shatkovska, H. I., Klymenko, M. M., and Radkevych, V. O., 2019. Psychological and pedagogical features of the career growth of vocational education's teachers. Opcion, 35 (Special Issue 23), pp. 763-779.

\section{Translated \& Transliterated}

Herliand, T., 2011. Strukturno-zmistovi aspekty profesiinoi kompetentnosti maibutnikh kvalifikovanykh robitnykiv [Structural and substantive aspects of professional competence of future qualified workers]. Naukovyi visnyk Instytutu profesiino-tekhnichnoi osvity NAPN Ukrainy. Profesiina pedahohika [Scientific herald of the Institute of vocational education and training of NAES Ukraine. Professional Pedagogy], 2, s. 30-34, [in Ukrainian].

Zakonodavstvo Ukrainy (Verkhovna Rada Ukrainy) [Legislation of Ukraine (Verkhovna Rada of Ukraine)], 2013. Pro Natsionalnu stratehiiu rozvytku osvity v Ukraini na period do 2021 roku: Ukaz Prezydenta Ukrainy vid 25.06.2013 № 344/2013 [On the National Strategy of Education Development in Ukraine until 2021: the Decree of the President as of June 25, 2013 No 344/2013]. [online] Dostupno: https://zakon3.rada.gov.ua/laws/show/344/2013 [Data zvernennia 10 Veresen 2019], [in Ukrainian].

Zakonodavstvo Ukrainy (Verkhovna Rada Ukrainy) [Legislation of Ukraine (Verkhovna Rada of Ukraine)], 2017. Pro osvitu: Zakon Ukrainy vid 05.09.2017 № 2145-VIII [On Education: the Law of Ukraine as of September 5, 2017 No 2145-VIII] [online]. Dostupno: http://zakon2.rada.gov.ua/laws/show/2145-19/page/ [Data zvernennia 10 Veresen 2019], [in Ukrainian].

Zakonodavstvo Ukrainy (Verkhovna Rada Ukrainy) [Legislation of Ukraine (Verkhovna Rada of Ukraine)], 2019. Pro skhvalennia Kontseptsii realizatsii derzhavnoi polityky u sferi profesiinoi (profesiino-tekhnichnoi) osvity "Suchasna profesiina (profesiino-tekhnichna) osvita» na period do 2027 roku: Rozporiadzhennia Kabinetu Ministriv Ukrainy vid 12.06.2019 № 419-r. [On the Approval of the Concept of Implementation of State Policy in the Field of Professional (Vocational) Education «Modern Professional (Vocational) Education» until 2027: the Decree of the Cabinet of Ministers of Ukraine as of June 12, 2019 No 419-r]. [online] Dostupno: https://zakon.rada.gov.ua/laws/show/419-2019-\%D1\%80 [Data zvernennia 10 Veresen 2019], [in Ukrainian].

Instytut profesiinykh kvalifikatsii [The Institute of Professional Qualifications], 2019. Analiz potreb rynku pratsi, vyklykiv ta mozhlyvostei na terytorii Skhidnoi Ukrainy: Poperednii zvit [Analyzing the Needs of the Labour Market, Challenges and Prospects in Eastern Ukraine: the Preliminary Report]. [online] Dostupno: <http://ipq.org.ua/upload/ files/files/03_Novyny/2019.05.15_Zvit/IPQ_Report_09.05.19.pdf $>$ [Data zvernennia 10 Veresen 2019], [in Ukrainian]. 
Kravets, S. H., 2019. Profesiinyi rozvytok suchasnoho pedahoha v konteksti reformuvannia profesiinoi osvity [The Professional Development of a Modern Teacher in the Context of Reforms in Professional Education]. V: Rozvytok profesiinoi maisternosti pedahoha v umovakh novoi sotsiokulturnoi realnosti: II Mizhnarodna nauk.-prakt. konf. [Developing Professional Skills in Teachers under the New Sociocultural Conditions: the 2nd International Scientific and Practical Conference], Ch. 1. Ternopil, Ukraina, 11-12 Kviten. 2019. Ternopil: Taip, [in Ukrainian].

Kravets, S. H., Kravets, Yu. I., Derevianko, N. P. ta Oliferchuk, O. H., 2014. Pedahohichni osnovy formuvannia zmistu pidhotovky kvalifikovanykh robitnykiv za intehrovanymy profesiiamy: posibnyk [The Pedagogical Principles of Building the Content of Training of Skilled Workers for Integrated Professions: a Textbook]. Kyiv: Polihrafservis, [in Ukrainian].

Lukianova, L., 2017. Zakonodavche zabezpechennia osvity doroslykh: zarubizhnyi dosvid [The Legal Framework of Adult Education: the International Experience]. Kyiv: DKS-Tsentr, [in Ukrainian].

Ministerstvo osvity Ukrainy, 2018. Pro zatverdzhennia Kontseptsii rozvytku pedahohichnoi osvity: Nakaz MON Ukrainy vid 16.07.2018 №776 [On the Approval of the Concept of Teacher Education Development: the Order of the Ministry of Education and Science of Ukraine as of July 16, 2018 No 776]. [online] Dostupno: https://mon.gov.ua/ua/ npa/pro-zatverdzhennya-koncepciyi-rozvitku-pedagogichnoyi-osviti. [Data zvernennia 10 Veresen 2019], [in Ukrainian].

Radkevych, V. O., Luzan, P. H. ta Kravets, S. H., 2017. Standartyzatsiia profesiinoi osvity v konteksti yevrointehratsiinykh protsesiv [Standardization of Professional Education in the Context of European Integration]. V: Naukove zabezpechennia rozvytku osvity v Ukraini: aktualni problemy teorii i praktyky (do 25-richchia NAPN Ukrainy) [The Scientific Support of Education Development in Ukraine: Some Relevant Problems of Theory and Practice]. Kyiv: Vydavnychyi dim «Sam», s. 259-267, [in Ukrainian].

Sorokvashyn, S. V., 2018. Formuvannia informatsiino-komunikatsiinoi kompetentnosti maibutnikh kvalifikovanykh robitnykiv budivelnoi haluzi u protsesi profesiinoi pidhotovky [Developing Informational and Communicative Competency in Future Skilled Workers of the Building Industry during Professional Training]. Kandydat nauk. VNZ «Universytet imeni Alfreda Nobelia», [in Ukrainian].

Bazyl, L. O., Shatkovska, H. I., Klymenko, M. M., and Radkevych, V. O., 2019. Psychological and pedagogical features of the career growth of vocational education's teachers. Opcion, 35 (Special Issue 23), 763-779, [in English].

\section{Технологія розвитку професійної компетентності майстрів виробничого навчання}

\section{Світлана Кравець,}

кандидат педагогічних наук, старший науковий співробітник лабораторії дистанційного професійного навчання Інституту професійно-технічної освіти НАПН України

\section{Реферат.}

Актуальність безперервного професійного розвитку сучасних педагогічних працівників ЗП(ПТ)О зумовлюється інноваційними змінами в освітній галузі, модернізацією педагогічних та виробничих технологій, створенням ефективних моделей і механізмів підготовки висококваліфікованих кадрів. Професійний розвиток сучасного майстра виробничого навчання співвідноситься з розвитком його професійної компетентності, інтегруючи системне “нарощування" нових знань і досвіду. $\mathrm{O}$.

Мета: обгрунтувати технологію розвитку професійної компетентності майстра виробничого навчання у ЗП(ПТ)

Методи: теоретичний аналіз наукових праць, вивчення практичного досвіду, систематизація й узагальнення, педагогічний експеримент.

Результати. Результати опитування педагогічних працівників (у т.ч. і майстрів виробничого навчання) щодо сформованості професійних мотивів засвідчують: високий рівень - 29\%, достатній - 56\%, середній - 15\%; за підсумками самооцінювання майстрами виробничого навчання готовності до реалізації функції “професійний розвиток": високий рівень - 48\%, достатній - 47\%, середній $-5 \%$. 3'ясовано, що в умовах створення сучасних моделей педагогічної освіти виникає необхідність пошуку оптимальних технологій розвитку професійної компетентності майстрів виробничого навчання. Алгоритм проектування технології розвитку професійної компетентності майстрів виробничого навчання ЗП(ПТ)О включає: науковий (визначення та дотримання цільових орієнтирів, завдань, методологічних засад, принципів професійної освіти), процесуальний (моделювання змісту, форм та методів розвитку професійної компетентності) та результативний (проведення діагностики рівня сформованості професійної компетентності майстрів виробничого навчання на основі відповідних методик та самоаналізу) аспекти.

Висновки: технологію розвитку професійної компетентності майстрів виробничого навчання ЗП(ПТ)О представлено як організований за відповідним алгоритмом психолого-педагогічний процес, реалізація якого гарантує досягнення результату - професійного розвитку особистості майстра виробничого навчання.

Ключові слова: професійний розвиток, професійна компетентність, майстер виробничого навчання, технологія розвитку професійної компетентності майстрів виробничого навчання. 